\title{
Geology and Assessment of Undiscovered Oil and Gas Resources of the Zyryanka Basin Province, 2008
}

Chapter $\mathrm{X}$ of

The 2008 Circum-Arctic Resource Appraisal

Professional Paper 1824

U.S. Department of the Interior

U.S. Geological Survey 
Cover. Eocene strata along the north side of Van Keulenfjorden, Svalbard, include basin-floor fan, marine slope, and deltaic to fluvial depositional facies. The age and facies of these strata are similar to Tertiary strata beneath the continental shelves of Arctic Eurasia, thus providing an analog for evaluating elements of those petroleum systems. Relief from sea level to top of upper bluff is approximately 1,500 feet. Photograph by David Houseknecht. 


\section{Geology and Assessment of Undiscovered Oil and Gas Resources of the Zyryanka Basin Province, 2008}

By Timothy R. Klett and Janet K. Pitman

Chapter X of

The 2008 Circum-Arctic Resource Appraisal

Edited by T.E. Moore and D.L. Gautier

Professional Paper 1824 


\title{
U.S. Department of the Interior RYAN K. ZINKE, Secretary
}

\section{U.S. Geological Survey William H. Werkheiser, Acting Director}

\author{
U.S. Geological Survey, Reston, Virginia: 2017
}

For more information on the USGS — the Federal source for science about the Earth, its natural and living resources, natural hazards, and the environment-visit https://www.usgs.gov or call 1-888-ASK-USGS.

For an overview of USGS information products, including maps, imagery, and publications, visit https://store.usgs.gov.

Any use of trade, firm, or product names is for descriptive purposes only and does not imply endorsement by the U.S. Government.

Although this information product, for the most part, is in the public domain, it also may contain copyrighted materials as noted in the text. Permission to reproduce copyrighted items must be secured from the copyright owner.

Suggested citation:

Klett, T.R., and Pitman, J.K., 2017, Geology and assessment of undiscovered oil and gas resources of the Zyryanka Basin Province, 2008, chap. X of Moore, T.E., and Gautier, D.L., eds., The 2008 Circum-Arctic Resource Appraisal: U.S. Geological Survey Professional Paper 1824, 11 p., https://doi.org/10.3133/pp1824X.

ISSN 2330-7102 (online) 


\section{The 2008 Circum-Arctic Resource Appraisal}

\section{Chapters}

A. Introduction to the 2008 Circum-Arctic Resource Appraisal (CARA) Professional Paper By Donald L. Gautier and Thomas E. Moore

B. Methodology for Assessment of Undiscovered Oil and Gas Resources for the 2008 Circum-Arctic Resource Appraisal

By Ronald R. Charpentier

\section{North America}

C. Geology and Assessment of Undiscovered Oil and Gas Resources of the Chukchi Borderland Province, 2008

By Kenneth J. Bird and David W. Houseknecht

D. Geology and Assessment of Undiscovered Oil and Gas Resources of the Hope Basin

Province, 2008

By Kenneth J. Bird, David W. Houseknecht, and Janet K. Pitman

E. Geology and Assessment of Undiscovered Oil and Gas Resources of the Arctic Alaska Petroleum Province, 2008

By David W. Houseknecht, Kenneth J. Bird, and Christopher P. Garrity

F. Geology and Assessment of Undiscovered Oil and Gas Resources of the Yukon Flats Basin Province, 2008

By Kenneth J. Bird and Richard G. Stanley

G. Geology and Assessment of Undiscovered Oil and Gas Resources of the Northwest Canada Interior Basins Province, Arctic Canada, 2008

By Marilyn E. Tennyson and Janet K. Pitman

H. Geology and Assessment of Undiscovered Oil and Gas Resources of the Franklinian Shelf Province, Arctic Canada and North Greenland, 2008

By Marilyn E. Tennyson and Janet K. Pitman

I. Geology and Assessment of Undiscovered Oil and Gas Resources of the Sverdrup Basin Province, Arctic Canada, 2008

By Marilyn E. Tennyson and Janet K. Pitman

\section{Greenland}

J. Geology and Assessment of Undiscovered Oil and Gas Resources of the West GreenlandEast Canada Province, 2008

By Christopher J. Schenk 
K. Geology and Assessment of Undiscovered Oil and Gas Resources of the East Greenland Rift Basins Province, 2008

By Donald L. Gautier

\section{North Atlantic Ocean}

L. Geology and Assessment of Undiscovered Oil and Gas Resources of the Jan Mayen Microcontinent Province, 2008

By Thomas E. Moore and Janet K. Pitman

\section{Eurasia}

M. Geology and Assessment of Undiscovered Oil and Gas Resources of the Mezen' Basin Province, 2008

By Timothy R. Klett and Janet K. Pitman

N. Geology and Assessment of Undiscovered Oil and Gas Resources of the Timan-Pechora Basin Province, Russia, 2008

By Christopher J. Schenk

0. Geology and Assessment of Undiscovered Oil and Gas Resources of the East Barents Basins Province and the Novaya Zemlya Basins and Admiralty Arch Province

By Timothy R. Klett

P. Geology and Assessment of Undiscovered Oil and Gas Resources of the North Kara Basins and Platforms Province, 2008

By Timothy R. Klett and Janet K. Pitman

0. Geology and Assessment of Undiscovered Oil and Gas Resources of the Northern West Siberian Mesozoic Composite Total Petroleum System of the West Siberian Basin Province, Russia, 2008

By Christopher J. Schenk

R. Geology and Assessment of Undiscovered Oil and Gas Resources of the Yenisey-Khatanga Basin Province, 2008

By Timothy R. Klett and Janet K. Pitman

S. Geology and Assessment of Undiscovered Oil and Gas Resources of the Northwest Laptev Sea Shelf Province, 2008

By Timothy R. Klett and Janet K. Pitman

T. Geology and Assessment of Undiscovered Oil and Gas Resources of the Lena-Anabar Basin Province, 2008

By Timothy R. Klett and Janet K. Pitman 
U. Geology and Assessment of Undiscovered Oil and Gas Resources of the Tunguska Basin Province, 2008

By Christopher J. Wandrey and Timothy R. Klett

V. Geology and Assessment of Undiscovered Oil and Gas Resources of the Lena-Vilyui Basin Province, 2008

By Timothy R. Klett and Janet K. Pitman

W. Geology and Assessment of Undiscovered Oil and Gas Resources of the Laptev Sea Shelf Province, 2008

By Timothy R. Klett and Janet K. Pitman

X. Geology and Assessment of Undiscovered Oil and Gas Resources of the Zyryanka Basin Province, 2008

By Timothy R. Klett and Janet K. Pitman

Y. Geology and Assessment of Undiscovered Oil and Gas Resources of the East Siberian Sea Basin Province, 2008

By Kenneth J. Bird, David W. Houseknecht, and Janet K. Pitman

Z. Geology and Assessment of Undiscovered Oil and Gas Resources of the Vilkitskii Basin Province, 2008

By Kenneth J. Bird, David W. Houseknecht, and Janet K. Pitman

AA. Geology and Assessment of Undiscovered Oil and Gas Resources of the Long Strait Province, Russian High Arctic, 2008

By Kenneth J. Bird, David W. Houseknecht, and Janet K. Pitman

\section{Arctic Ocean}

BB. Geology and Assessment of Undiscovered Oil and Gas Resources of the Amerasia Basin Petroleum Province, 2008

By David W. Houseknecht, Kenneth J. Bird, and Christopher P. Garrity

CC. Geology and Assessment of Undiscovered Oil and Gas Resources of the LomonosovMakarov Province, Central Arctic Ocean, 2008

By Thomas E. Moore, Kenneth J. Bird, and Janet K. Pitman

DD. Geology and Assessment of Undiscovered Oil and Gas Resources of the Eurasia Basin Province, Eastern Arctic Ocean, 2008

By Thomas E. Moore and Janet K. Pitman 


\section{Contents}

Abstract.

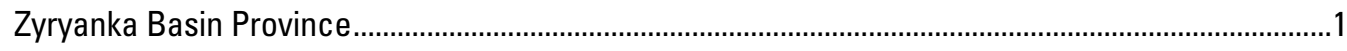

Province Boundary Definition .......................................................................................................

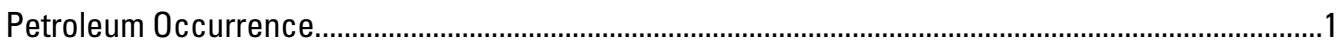

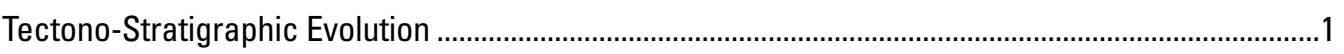

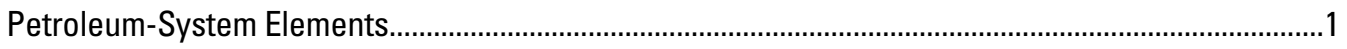

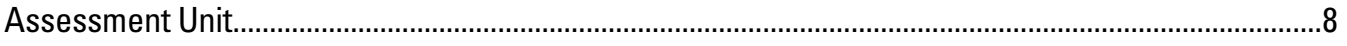

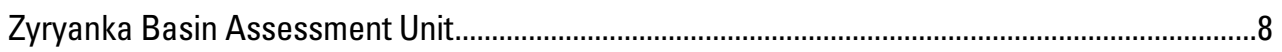

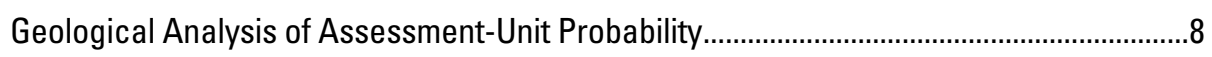

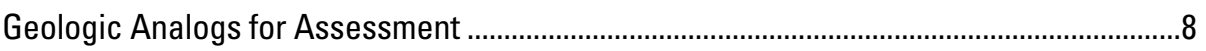

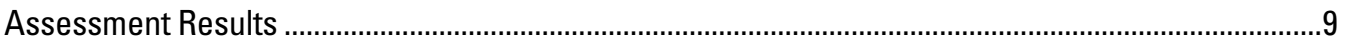

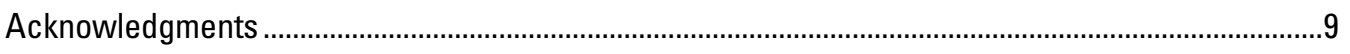

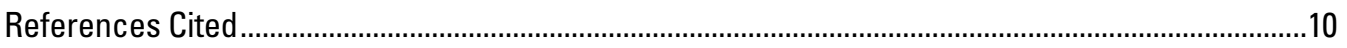

\section{Appendix}

[Available for download at https://doi.org/10.3133/pp1824X]

1. Input Data for the Zyryanka Basin Assessment Unit

\section{Figures}

1. Map of Zyryanka Basin Province, showing location of assessment unit

2. Structural map of the Zyryanka Basin Province, showing major structural features and approximate depth to economic basement.

3. Regional geologic cross section through the Zyryanka Basin Province ..........................3

4. Lithostratigraphic column and total-petroleum-system events chart for the Zyryanka

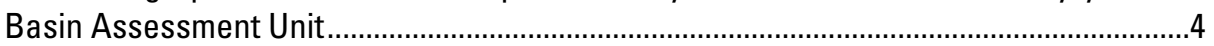

5. Petroleum-system burial-history models for pseudowells in the Zyryanka Basin showing degree of thermal maturity

\section{Table}

1. Assessment results for conventional undiscovered petroleum resources in the Zyryanka Basin Province. 


\title{
Chapter X
}

\section{Geology and Assessment of Undiscovered Oil and Gas Resources of the Zyryanka Basin Province, 2008}

\author{
By Timothy R. Klett and Janet K. Pitman
}

\section{Abstract}

The U.S. Geological Survey (USGS) recently assessed the potential for undiscovered oil and gas resources of the Zyryanka Basin Province as part of the 2008 USGS Circum-Arctic Resource Appraisal program. The province is in the Russian Federation and is situated on the Omolon superterrane of the Kolyma block. The one assessment unit (AU) that was defined for this study, called the Zyryanka Basin AU, which coincides with the province, was assessed for undiscovered, technically recoverable, conventional resources. The estimated mean volumes of undiscovered resources in the Zyryanka Basin Province are $~ 72$ million barrels of crude oil, 2,282 billion cubic feet of natural gas, and 61 million barrels of natural-gas liquids. About 66 percent of the study area and undiscovered petroleum resources are north of the Arctic Circle.

\section{Zyryanka Basin Province}

\section{Province Boundary Definition}

The Zyryanka Basin Province encompasses the Zyryanka sedimentary basin of eastern Siberia (fig. 1). The geologic province is situated within the Kolyma block and the Omolon superterrane. The province crosses the Arctic Circle.

\section{Petroleum Occurrence}

Surface shows of natural gas have been observed in 10 places within the Zyryanka Basin. The natural gas contained 70 to 98 volume percent methane (Ulmishek, 1984; Kim, 1990) and as much as 0.11 volume percent heavier hydrocarbons (Ulmishek, 1984).

\section{Tectono-Stratigraphic Evolution}

The Zyryanka Basin Province is a Late Cretaceous and Cenozoic foreland basin that overlies Jurassic to Lower Cretaceous backarc basin deposits formed during Jurassic and Cretaceous accretion and deformation of the Kolyma block (Parfenov, 1992). The basin (and AU) is bounded by extensively deformed sedimentary rocks derived from Jurassic oceanic island-arc terranes (Parfenov, 1992; Parfenov and others, 1993). Major structural features of the province and approximate depth to economic basement are mapped in figure 2, and a geologic cross section is shown in figure 3.

\section{Petroleum-System Elements}

A single Mesozoic and Cenozoic composite total petroleum system (TPS) was identified for the Zyryanka province. Lithostratigraphic columns and a TPS events chart showing individual petroleum-system elements are shown in figures $4 A$ and $4 B$, respectively.

The most likely petroleum-source rocks are the Cenozoic El'gandin Formation, with $\sim 3.7$ weight percent total organic carbon (TOC) content; and the Darkylakh Formation, with 2.3 weight percent TOC content (Ulmishek, 1984; Ivanov, 1987; Syundyukov and Gaiduk, 1996). Other probable source rocks include carbonaceous continental and shallow-marine Lower Cretaceous mudstone, with $\sim 1$ weight percent TOC content (Ulmishek, 1984), and Upper Jurassic continental slope and basin marine mudstones (flysch), with $\sim 1$ to 3 weight percent TOC content (Ulmishek, 1984; Ivanov, 1987; Syundyukov and Gaiduk, 1996). Petroleum source rocks might also exist in the Paleozoic section, including Silurian graptolitic mudstone; Devonian organic-rich (slightly bituminous) mudstone, with as much as 9 weight percent TOC content; and Carboniferous organic-rich tuffaceous mudstone, 


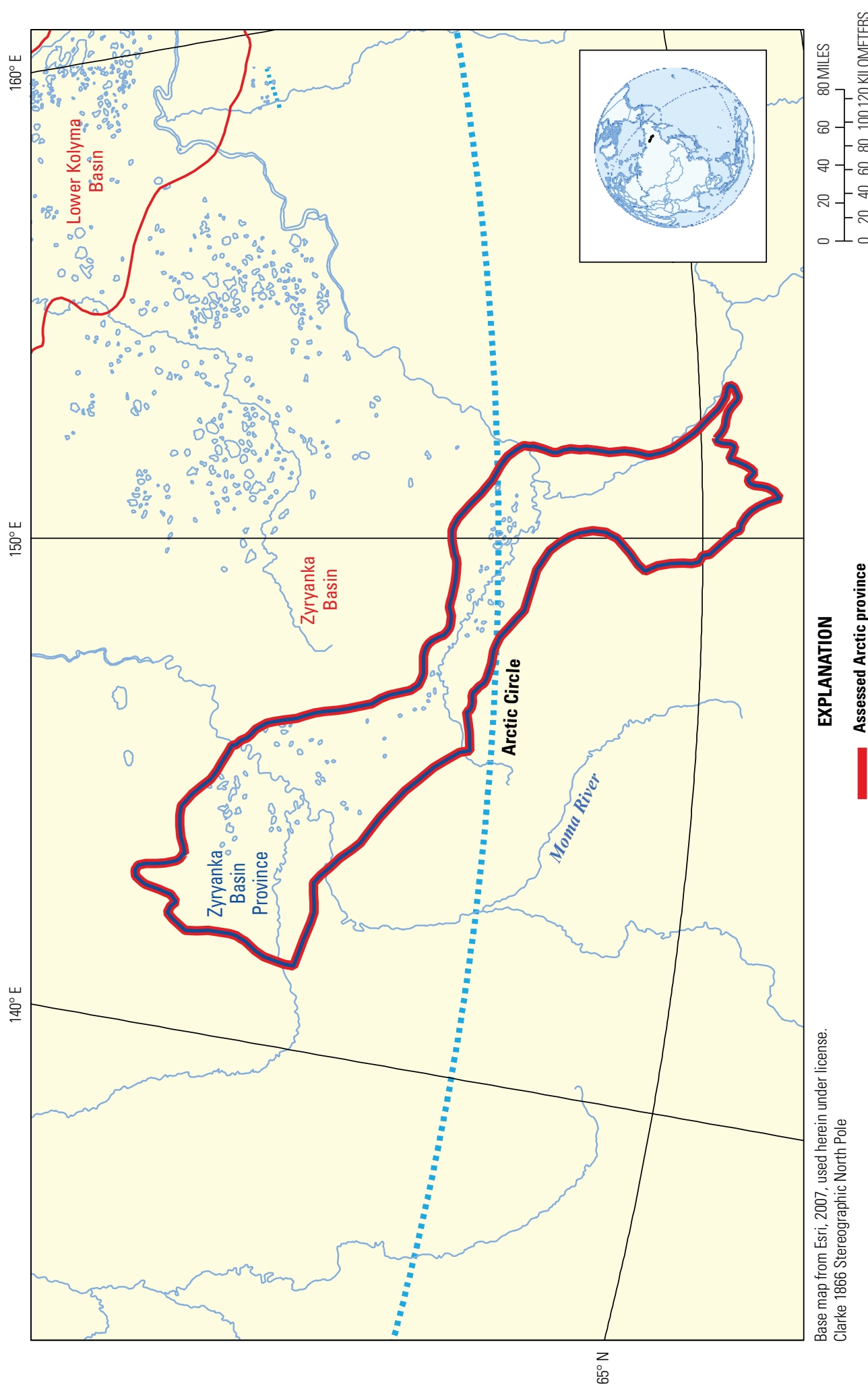

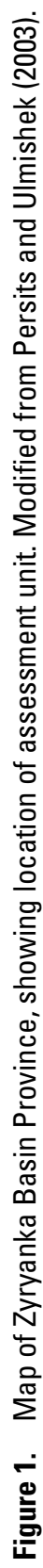




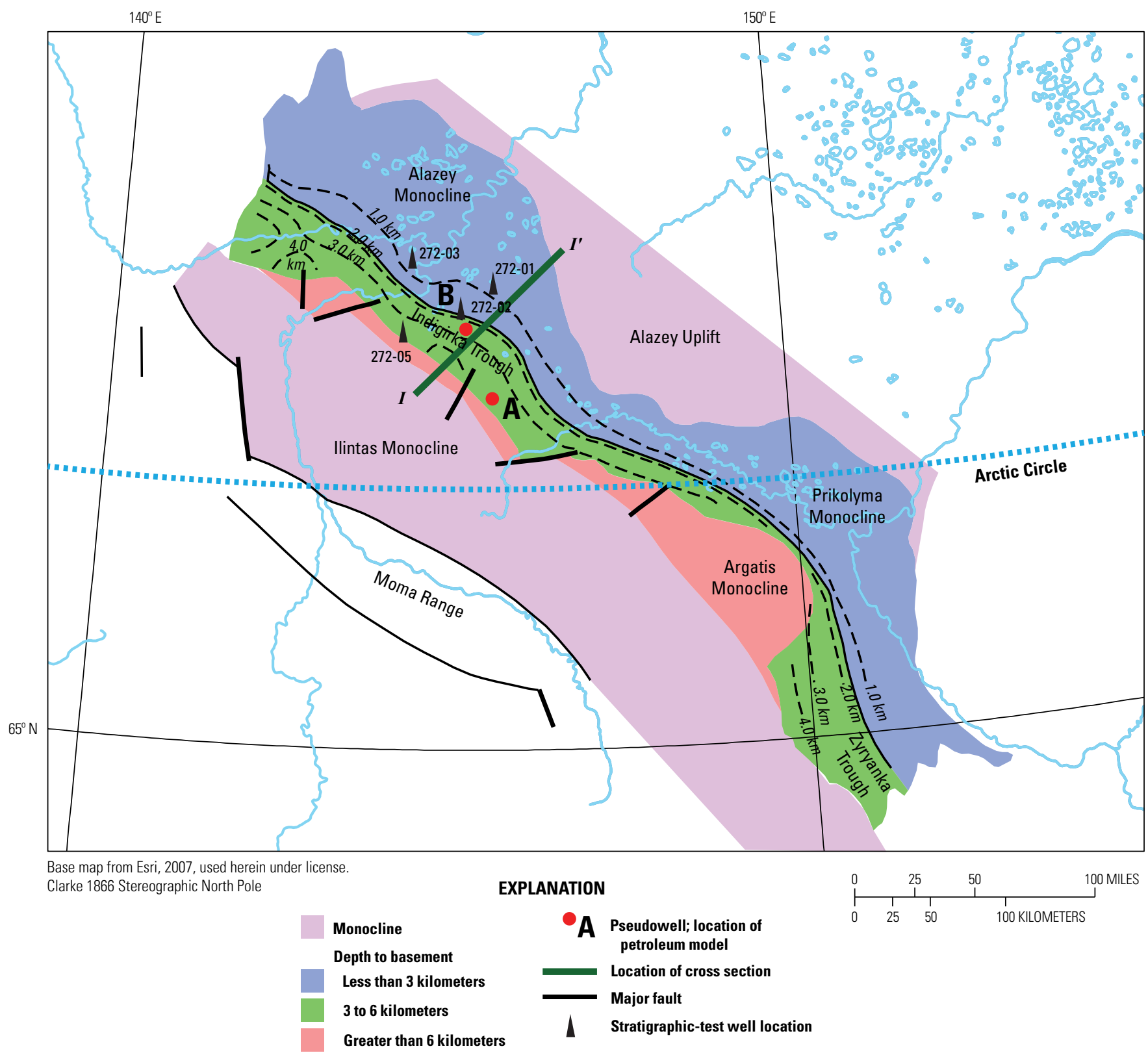

Figure 2. Structural map of the Zyryanka Basin Province, showing major structural features and approximate depth to economic basement. Modified from Ulmishek (1984) and Syundyukov and Gaiduk (1997).

$I$

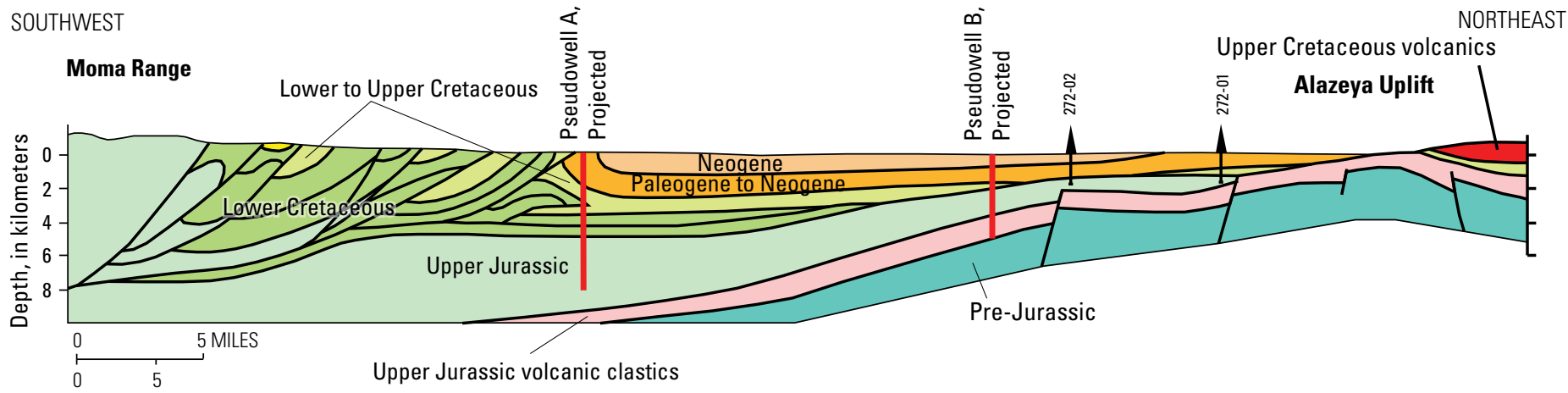

Figure 3. Regional geologic cross section through the Zyryanka Basin Province. Vertical red lines, wells or pseudowells used for petroleum-generation models. Modified from Parfenov (1991). 
$\boldsymbol{A}$

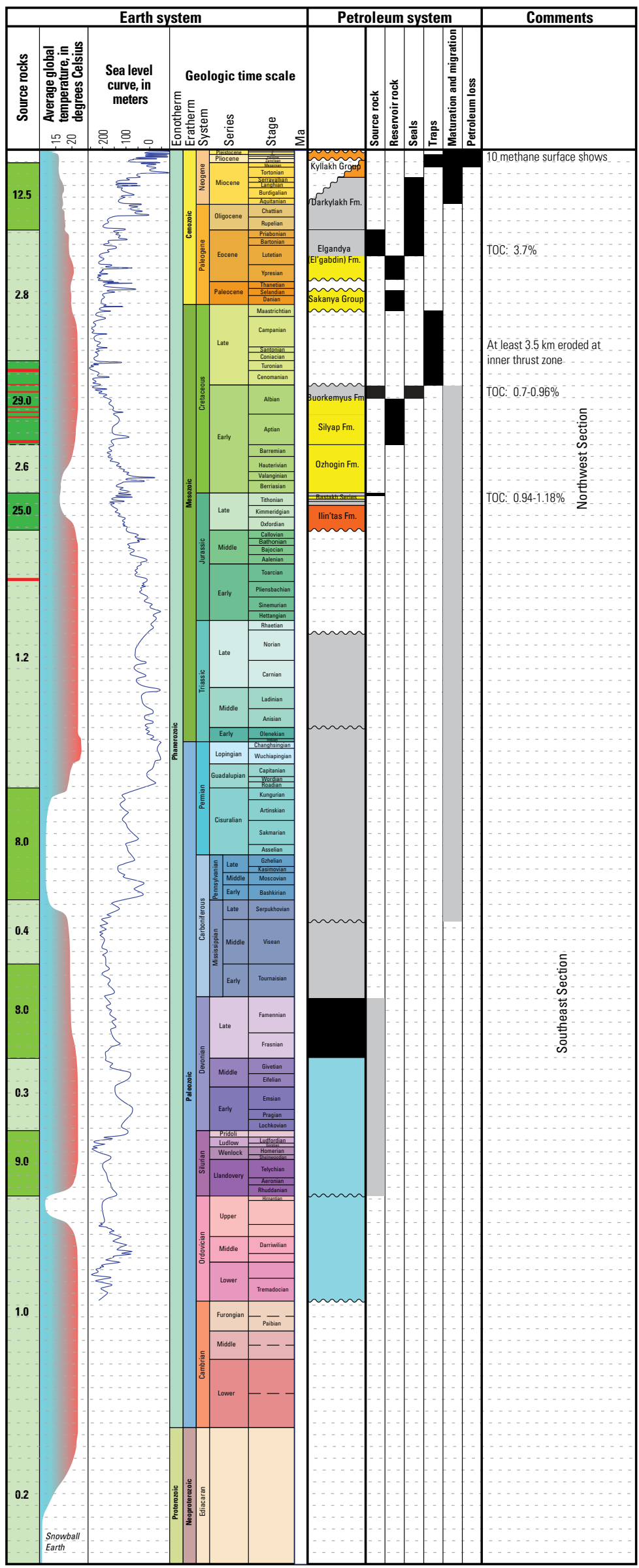

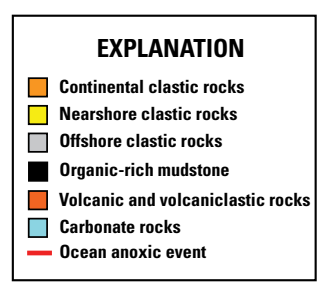

Figure 4. Lithostratigraphic column $(A)$ and total-petroleum-system events chart $(B)$ for the Zyryanka Basin Assessment Unit. Source rocks column shows the percent of the world's total petroleum reserves generated by source (modified from Ulmishek and Klemme, 1990). Average global temperature data is from Frakes and others (1992) and Barrett (2003). Sea level curve is from Golonka and Kiessling (2002) and Hardenbol and others (1998). Geologic time scale is that of Gradstein and others (2004). Data from Ulmishek (1984), Kim (1990), Syundyukov and Gayduk (1996), and Paech and others (2000). 
$B$

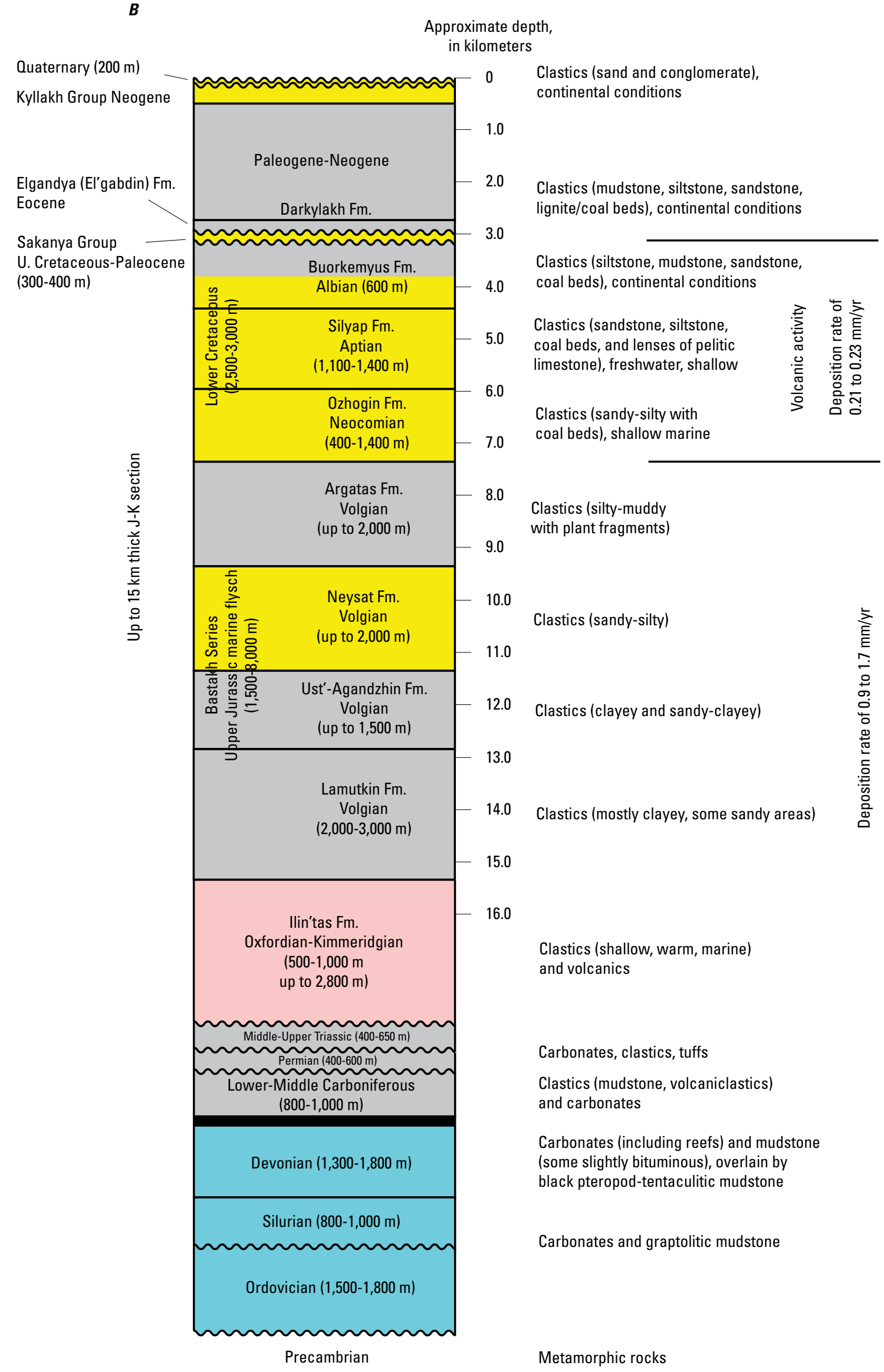

Figure 4.-Continued 
with 3 to 4 weight percent TOC content (Ivanov, 1987; Syundyukov and Gaiduk, 1996). Because of presumed mixing of petroleum, a single Paleozoic and Mesozoic composite TPS was defined.

On the basis of petroleum-generation modeling, Paleozoic source rocks are thermally overmature, and so any petroleum generation from these rocks most likely occurred before Cretaceous deformation and trap formation (fig. 5). Upper Jurassic source rocks are thermally mature to overmature with respect to gas generation. Lower Cretaceous source rocks entered the oil-maturation window in Neogene time and remained there until recently. Some petroleum may have been dispersed by Cenozoic uplift and erosion of as much as $3.5 \mathrm{~km}$ in the fold and thrust belt. Cenozoic source rocks are immature. Petroleum could have migrated vertically along faults or by short lateral migration into reservoirs juxtaposed to source rocks by fault displacements.

Main reservoir rocks and seals would be the Lower Cretaceous Buorkemyus and Silyap Formations and the Paleogene El'gandin Formation, respectively (fig. $4 B$ ). The sandstones have a fair reservoir quality (12-14 percent porosity

$\boldsymbol{A}$
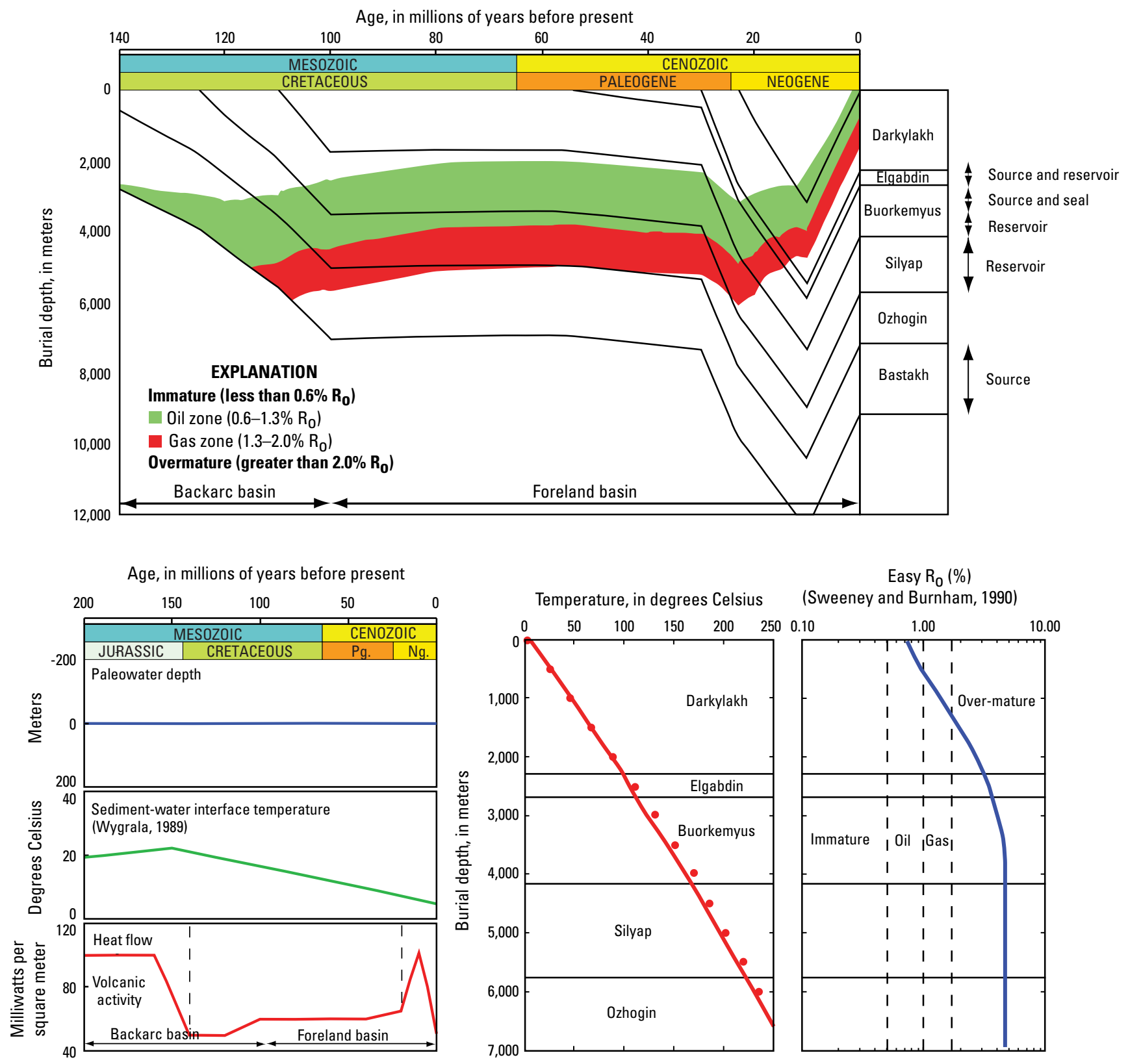

Figure 5. Petroleum-system burial-history models for pseudowells $(A, B)$ in the Zyryanka Basin showing degree of thermal maturity. See figure 1 for locations of wells. $R_{0^{\prime}}$ vitrinite reflectance, in percent (\%). Data from Duchkov and others (1982), Fujita and others (1990), and Syundyukob and Gayduk (1996). Petromod references: Wygrala (1989), Sweeney and Burnham (1990), and Integrated Exploration Systems (2008). 
and 7 millidarcies of permeability, and 18 percent porosity, respectively (Ulmishek, 1984; Ivanov, 1987; Syundyukov and Gaiduk, 1996). Overlying alternating siltstone and mudstone of the upper Buorkemyus Formation (600 m thick) and mudstone of the upper El'gandin and Darkylakh Formations (total, $90 \mathrm{~m}$ thick) would provide adequate seals (Ulmishek, 1984; Ivanov, 1987; Syundyukov and Gaiduk, 1996).

Sandstones of the Upper Jurassic Bastakh Series and Lower Cretaceous Ozhogin Formation have poor reservoir quality ( $<6$ percent porosity and $<0.1$ millidarcies of permeability).
Additionally, seals are poor, with thick mudstone present only in the lower part of the interval (Ulmishek, 1984; Ivanov, 1987; Syundyukov and Gaiduk, 1996).

Other Paleozoic and Triassic intervals lack adequate reservoir quality and seals. Clastic rocks are subordinate and have little intergranular porosity. In addition, the presence and extent of seals are unknown, although Devonian anhydrite might serve as a seal in places (Ulmishek, 1984).

Traps formed during Cretaceous deformation (Ulmishek, 1984; Ivanov, 1987; Syundyukov and Gaiduk, 1996). Uplifted

B

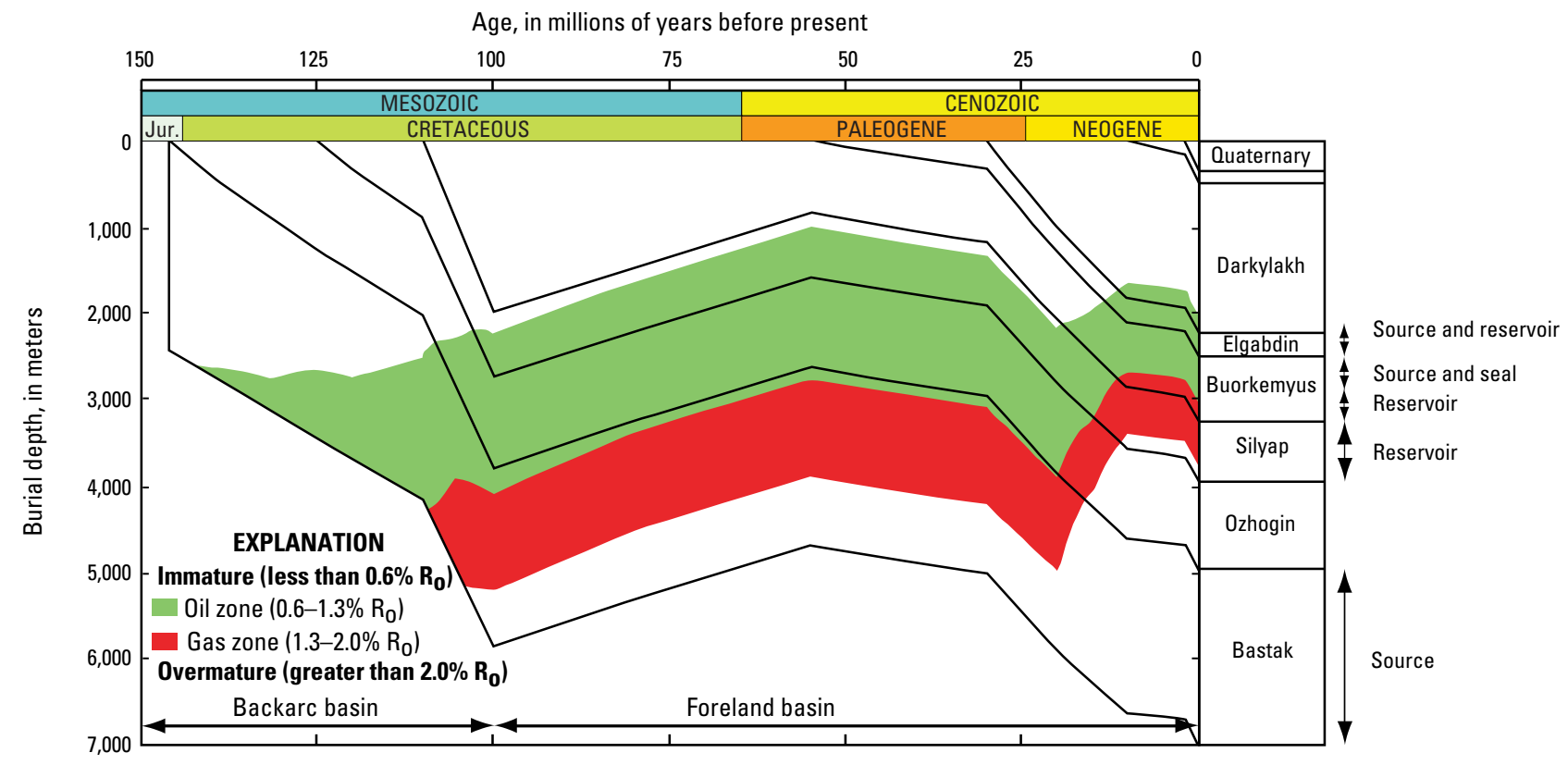

Boundary parameters

Age, in millions of years before present

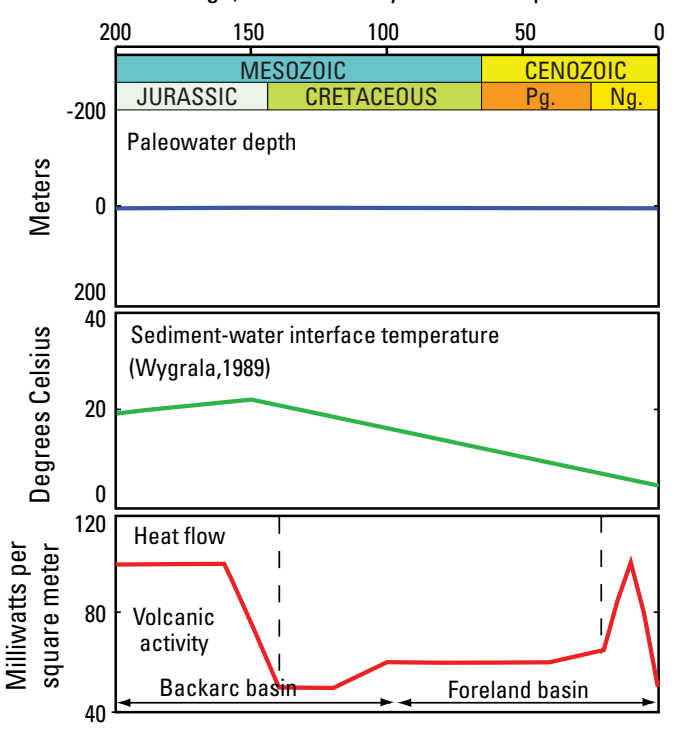

Temperature, in degrees Celsius

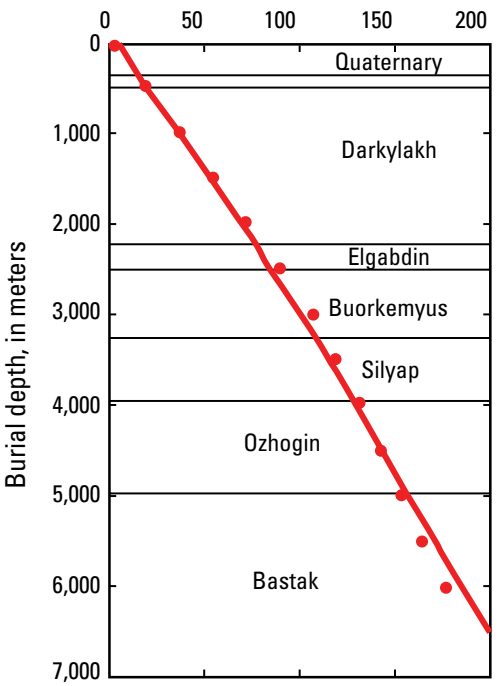

Easy $\mathrm{R}_{0}(\%)$

(Sweeney and Burnham, 1990)

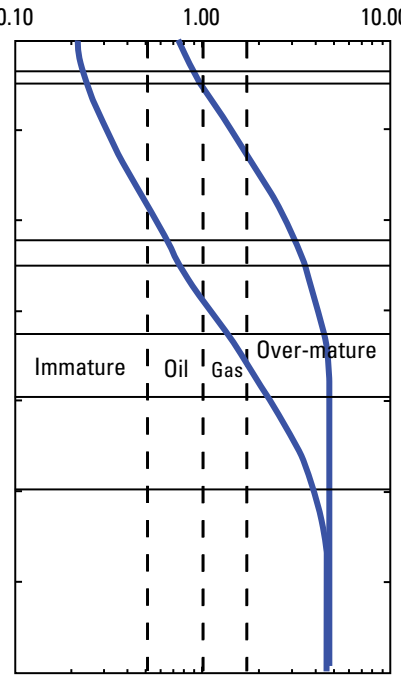

Figure 5.-Continued 
basement blocks formed local highs and steps expressed in Upper Jurassic and Lower Cretaceous units, and pinchouts of Upper Jurassic and Lower Cretaceous units may be present along the Alazey monocline to the north and east. Frontal unbreached anticlines of early Miocene and Pliocene age may provide trap configurations along the thrust belt.

The most probable occurrence for petroleum accumulations in the Zyryanka Basin Province is in Upper Jurassic and Lower Cretaceous reservoirs, which would be charged by gas-prone Upper Jurassic and Lower Cretaceous source rocks. However, Cenozoic uplift and erosion of at least $3.5 \mathrm{~km}$ may have dispersed some petroleum accumulations. Paleozoic and Triassic strata contain few reservoir and seal rocks, and petroleum-source rocks are absent in the northeastern part of the province. Source rocks are overmature elsewhere. Petroleum generation probably occurred before the Late Jurassic and Early Cretaceous collision, and so petroleum accumulations may not be preserved.

\section{Assessment Unit}

\section{Zyryanka Basin Assessment Unit}

One AU is defined, the Zyryanka Basin (12520101), which encompasses the whole province. Stratigraphically, the AU includes the entire Paleozoic and Mesozoic section. At least four stratigraphic test wells were drilled.

\section{Geological Analysis of Assessment-Unit Probability}

The overall probability that the Zyryanka Basin AU contains at least one petroleum accumulation equal to or greater than the minimum field size of 50 million barrels of oil equivalent (MMBOE) is considered to be $\sim 50$ percent (0.504).

Charge Probability.-Charge probability was estimated at 0.80 because potential source rocks have been identified and several natural gas seeps have been located, but economic petroleum accumulations are unknown. Potential source rocks include carbonaceous continental and shallow-marine Lower Cretaceous and possible Paleogene and Neogene clastic sedimentary rocks. Other possible source rocks could include Upper Jurassic (Volgian or Tithonian) continental slope and basin marine mudstone (flysch, turbidites, and gravity flows) and, remotely, Silurian and Devonian and Carboniferous organic-rich mudstone.

Rock Probability:-Rock probability was estimated at 0.90 because reservoir quality and seal integrity are known from outcrop studies. Main reservoir rocks and seals would be the Lower Cretaceous Buorkemyus and Silyap Formations and the Paleogene El'gandin Formation. Sandstones in these units have a fair reservoir quality (12-14 percent porosity, 7 millidarcies permeability, and 18 percent porosity, respectively). Overlying alternating siltstone and mudstone of the upper part of the Buorkemyus Formation (600 m thick) and mudstone of the upper parts of the El'gandin and Darkylakh Formations (total, $90 \mathrm{~m}$ thick) would provide adequate seals; other Paleozoic and Mesozoic intervals lack adequate reservoir quality and seals. Traps formed during Cretaceous deformation. Uplifted basement blocks, resulting in local highs and steps expressed in Upper Jurassic and Lower Cretaceous units, as well as pinchouts of Upper Jurassic and Lower Cretaceous intervals, may be present along the Alazey monocline to the north and east (fig. 2). Frontal unbreached anticlines of early Miocene and Pliocene age may provide trap configurations along the thrust belt.

Timing and Preservation Probability.-Timing and preservation probability was estimated at 0.70 because maturation of potential source rocks would have occurred after Late Mesozoic deformation but before Neogene uplift. Paleozoic and Upper Jurassic mudstone units are overmature, so any petroleum generation from these source rocks most likely occurred before Cretaceous deformation and trap formation. Lower Cretaceous source rocks entered the oilmaturation window in Neogene time and has remained there until recently. Some petroleum may have been dispersed by Cenozoic uplift and erosion in the fold and thrust belt. Cenozoic source rocks are immature. Petroleum could have migrated vertically along faults or by short lateral migration into reservoirs juxtaposed to source rocks by fault displacements.

\section{Geologic Analogs for Assessment}

The Zyryanka Basin AU area is $\sim 56,000 \mathrm{~km}^{2}$, with no offshore portion; $\sim 66$ percent of the AU is north of the Arctic Circle. One analog dataset of 24 AUs from within the USGS Analog Database (Charpentier and others, 2008), representing foreland architecture, clastic depositional systems, and compressional-trap systems without salt-related traps and with discovered fields of at least 50 MMBOE, was used to estimate the number and sizes of undiscovered petroleum accumulations.

Number of Undiscovered Accumulations.-The number of undiscovered accumulations was estimated by comparing field densities (estimated number of undiscovered accumulations plus number of discovered accumulations exceeding 50 MMBOE per $1,000 \mathrm{~km}^{2}$ ) of the analog dataset. The density of only discovered accumulations, which is generally smaller, was used to calibrate the actual densities used for the Zyryanka Basin AU. Densities of $0,0.2$, and 1.0 (minimum, median, and maximum, respectively) were used for this AU. The median and maximum densities are less than those of the analog dataset because Late Mesozoic and Neogene tectonic events might have destroyed larger petroleum accumulations that could have formed previously. An oil/gas mixture of $0.05(0.0-0.15)$ was assumed (see appendix). Naturalgas accumulations are probably present, with only minor amounts of crude oil. 
Sizes of Undiscovered Accumulations. - The minimum accumulation size is the CARA-defined 50 MMBOE. The median size of crude-oil and natural-gas accumulations (100 MMBOE) was estimated (see appendix) to be slightly less than the mean and median of the median size of the analog dataset because of a potential lack of preservation of larger accumulations. The lowprobability maximum crude-oil-accumulation size (800 MMBOE) approximately equals the median of the largest discovered field size of the analog dataset.

Expected Size of Maximum Undiscovered Accumulation.The expected maximum sizes of undiscovered crude-oil and natural-gas accumulations (both $250 \mathrm{MMBOE}$ ) are based on the distribution of the sizes of discovered fields in the analog dataset (particularly the median of the maximum discovered field sizes), excluding outlying values that do not represent this AU.

Petroleum Composition and Properties of Undiscovered Accumulations. - Coproducts and petroleum-quality properties were estimated from global statistics.

\section{Assessment Results}

The assessment results for the Zyryanka Basin Province are summarized in table 1, which represents the assessment of the full geographic extent of the AU (fig. 1). Estimates represent undiscovered, technically recoverable, conventional petroleum resources.

The mean undiscovered crude-oil resource in the Zyryanka Basin AU (and Province) is $72 \mathrm{MMB}$, with a 95-percent probability (F95) of 0 MMB, a 50-percent probability (F50) of $0 \mathrm{MMB}$, and a 5-percent probability (F5) of $286 \mathrm{MMB}$ (table 1). The AU probability is 0.504 (see appendix). The mean volume of undiscovered nonassociated natural-gas resource is $2,176 \mathrm{BCF}$, with an $\mathrm{F} 95$ of $0 \mathrm{BCF}$, an F50 of 942 BCF, and an F5 of 7,746 BCF. The largest expected size of an undiscovered oil field is $\sim 132 \mathrm{MMB}$, and the largest expected size of an undiscovered gas field is $\sim 1,296 \mathrm{BCF}$ (not reported in appendix).

The total estimated mean undiscovered petroleum resources in the Zyryanka Basin Province north of the Arctic Circle are $72 \mathrm{MMB}$ of crude oil, 2,282 BCF of associated and nonassociated natural gas, and $61 \mathrm{MMB}$ of natural-gas liquid (NGL) (table 1). Additional statistics are listed in table 1.

The geologic probabilities of the Zyryanka Basin AU were determined on the basis of a consideration of the geology of this province but also on the geologic probabilities assigned to AUs during the assessment of all Arctic basins. Thus, the geologic probabilities were consistently applied throughout the Arctic in this assessment.

\section{Acknowledgments}

We are extremely grateful to the USGS Library staff for their help in obtaining rare, hard-to-find geological articles from the Russian scientific literature. We also thank Feliks Persits for Geographic Information System (GIS) support, and Donald L. Gautier and Gregory F. Ulmishek for their reviews of the manuscript.

Table 1. Assessment results for conventional undiscovered petroleum resources in the Zyryanka Basin Province.

[All data are fully risked estimates. AU, assessment unit; BCF, billion cubic feet; MMB, million barrels; NGL, natural-gas liquid; TPS, total petroleum system.

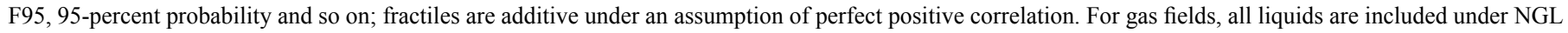
category. N/A, not applicable]

\begin{tabular}{|c|c|c|c|c|c|c|c|c|c|c|c|c|c|c|}
\hline \multirow{2}{*}{$\begin{array}{l}\text { Total petroleum } \\
\text { systems and } \\
\text { assessment units }\end{array}$} & \multirow{2}{*}{$\begin{array}{l}\text { AU prob- } \\
\text { ability }\end{array}$} & \multirow{2}{*}{$\begin{array}{l}\text { Field } \\
\text { type }\end{array}$} & \multicolumn{4}{|c|}{ Oil (MMB) } & \multicolumn{4}{|c|}{ Gas (BCF) } & \multicolumn{4}{|c|}{ NGL (MMB) } \\
\hline & & & F95 & F50 & F5 & Mean & F95 & F50 & F5 & Mean & F95 & F50 & F5 & Mean \\
\hline \multicolumn{15}{|c|}{ Zyryanka Basin Province } \\
\hline \multirow[t]{2}{*}{ Zyryanka Basin AU } & 0.504 & Oil & 0 & & 286 & 72 & 0 & 0 & 496 & 296 & 0 & & 13 & 3 \\
\hline & & Gas & $\mathrm{N} / \mathrm{A}$ & $\mathrm{N} / \mathrm{A}$ & $\mathrm{N} / \mathrm{A}$ & $\mathrm{N} / \mathrm{A}$ & 0 & 942 & 7,746 & 1,039 & 0 & 22 & 209 & 58 \\
\hline $\begin{array}{l}\text { Total undiscovered } \\
\text { petroleum resources, } \\
\text { Zyryanka Basin } \\
\text { Province }\end{array}$ & & & 0 & & 286 & 72 & 0 & 942 & 8,282 & 1,335 & 02 & 2 & 222 & 61 \\
\hline
\end{tabular}




\section{References Cited}

Barrett, P., 2003, Paleoclimatology_cooling a continent: Nature, v. 421, p. 221-223.

Charpentier, R.R., Klett, T.R., and Attanasi, E.D., 2008, Database for assessment unit-scale analogs, exclusive of the United States: U.S. Geological Survey Open-File Report 2007-1404, 61 p.

Duchkov, A.D., Balobaev, V.T., Lysak, S.V., Sokolova, L.S., Devyatkin, V.N., Volod'ko, B.V., and Levchenko, A.N., 1982, The heat flow of Siberia: Geologiya i Geofizika, v. 23, no. 1, p. 42-51 (in English), p. 42-51. [In Russian.]

Frakes, L.A., Francis, J.E., and Syktus, J.I., 1992, Climate modes of the Phanerozoic - the history of the earth's climate over the past 600 million years: Cambridge, U.K., Cambridge University Press, $274 \mathrm{p}$.

Fujita, K., Cambray, F.M., and Velbel, M.A., 1990, Tectonics of the Laptev Sea and Moma Rift Systems, northeastern USSR: Marine Geology, v. 93, p. 95-118.

Golonka, J., and Kiessling, W., 2002, Phanerozoic time scale and definition of time slices, in Kiessling, W., Flügel, E., and Golonka, J., eds., Phanerozoic reef patterns: Society of Economic Paleontologists and Mineralogists Special Publication 72, p. 11-20.

Gradstein, F.M., Ogg, J.G., Smith, A.G., Agterberg, F.P., Bleeker, W., Cooper, R.A., Davydov, V., Gibbard, P., Hinnov, L.A., House, M.R., Lourens, L., Luterbacher, H.P., McArthur, J., Melchin, M.J., Robb, L.J., Shergold, J., Villeneuve, M., Wardlaw, B.R., Ali, J., Brinkhuis, H., Hilgen, F.J., Hooker, J., Howarth, R.J., Knoll, A.H., Laskar, J., Monechi, S., Plumb, K.A., Powell, J., Raffi, I., Röhl, U., Sadler, P., Sanfilippo, A., Schmitz, B., Shackleton, N.J., Shields, G.A., Strauss, H., Van Dam, J., van Kolfschoten, T., Veizer, J., and Wilson, D., 2004, A geologic time scale: Cambridge, U.K., Cambridge University Press, 589 p.

Hardenbol, J., Thierry, J., Farley, M.B., Jacquin, T., de Graciansky, P.-C., and Vail, P.R., 1998, Mesozoic and Cenozoic sequence chronostratigraphic framework for European basins, in de Graciansky, P.-C., Hardenbol, J., Jacquin, T., and Vail, P.R., eds., Mesozoic and Cenozoic sequence stratigraphy of European basins: Society of Economic Paleontologists and Mineralogists Special Publication 60, p. 3-13.

Integrated Exploration Systems [IES], 2008, Petromod 1D, version 10 software.

Ivanov, V.V., 1987, Sedimentary basins of northeast Asia: Petroleum Geology, v. 22, no. 6, p. 235-296 [translated from Akademiia Nauk SSSR Nauka, Dal'nevostoch, Nauchnykh Tsentr, 1985, 208 p.].
Kim, B.I., 1990, History of formation and oil-gas prospects of the Moma-Zyryan Depression: Petroleum Geology, v. 24, no. 3-4, p. 122-123 [translated from Tektonika Sibiri Nauka, Novosibirsk, 1980, v. 9, p. 72-79].

Paech, H-J., Prokopiev, A.V., von Gosen, W., Grinenko, O.V., Smetannikova, L.I., and Belolyubskij, I.N., 2000, New results of the Moma rift system and coeval structures in Yakutia, Russian Federation: Polarforschung, no. 68, p. 59-63.

Parfenov, L.M., 1991, Tectonics of the Verkhoyansk-Kolyma Mesozoides in the context of plate tectonics: Tectonophysics, v. 199 , p. 319-342.

Parfenov, L.M., 1992, Accretionary history of northeast Asia, in Thurston, D.K., and Fujita, K., eds., International Conference on Arctic Margins, Anchorage, 1992, Proceedings, p. 195-200.

Parfenov, L.M., Natapov, L.M., Sokolov, S.D., and Tsukanov, N.V., 1993, Terranes and accretionary tectonics of northeastern Asia: Geotectonics, v. 27, no. 1, p. 62-72.

Persits, F.M., and Ulmishek, G.F., 2003, Maps showing geology, oil and gas fields, and geologic provinces of the Arctic: U.S. Geological Survey Open-File Report 97-470-J, CD-ROM.

Sweeney, J.J., and Burnham, A.K., 1990, Evaluation of a simple model of vitrinite reflectance based on chemical kinetics: American Association of Petroleum Geologists Bulletin, v. 74, p. $1559-1570$.

Syundyukob (Syundyukov), I. Sh., and Gayduk (Gaiduk), V.V., 1996, Historical-genetic basis for oil-gas occurrence in Indigirka-Zyryanka downwarp: Petroleum Geology, v. 30, no. 1, p. 63-68, [translated from Neftegazonosnost' i voprosy osvoyeniya mestorozhdeniy nefti i gaza Yakuytii: Yakutsk, Yakutskiy Nauchnyi Tsentr, Sibirskoe Otdelenie Akademiia Nauk SSSR, 1990, p. 39-49]..

Syundyukov, I. Sh., and Gaiduk, V.V., 1997, Catagenesis of organic matter in Meso-Cenozoic deposits of the IndigirkaZyryanka trough and their petroleum potential: Russian Geology and Geophysics, v. 38, no. 4, p. 863-866.

Ulmishek, G.F., 1984, The geology and petroleum resources of basins in the Asian Arctic and offshore East Greenland: Lemont, Ill., Argonne National Laboratory Report ANL/EES-TM-247, p. 3440 .

Ulmishek, G.F., and Klemme, H.D., 1990, Depositional controls, distribution, and effectiveness of world's petroleum source rocks: U.S. Geological Survey Bulletin 1931, 59 p.

Wygrala, B.P., 1989, Integrated study of an oil field in the southern Po Basin, northern Italy: Berichte der Kernforschungsanlage Julich, no. 2313, 217 p. 


\section{Appendix. Input Data for the Zyryanka Basin Assessment Unit}

Appendix file is available online only, and may be accessed at https://doi.org/10.3133/pp1824X. 


\section{$\frac{2}{2}$}

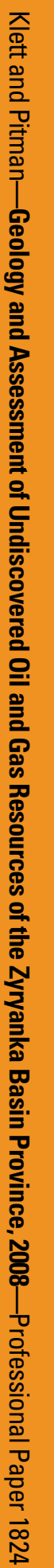

